\title{
Serum soluble (pro)renin receptor level as a prognostic factor in patients undergoing maintenance hemodialysis
}

\section{Yoshifumi Amari}

Moriguchi Keijinkai Hospital

Satoshi Morimoto ( $\nabla$ morimoto.satoshi@twmu.ac.jp )

Tokyo Women's Medical University

\section{Chikahito Suda}

Tokyo Women's Medical University

Takeshi lida

Moriguchi Keijinkai Hospital

Takatomi Yurugi

Moriguchi Keijinkai Hospital

\section{Yasuo Oyama}

Neyagawa Keijinkai Clinic

Naoki Aoyama

Moriguchi Keijinkai Clinic

Fumitaka Nakajima

Kadoma Keijinkai Clinic

Atsuhiro Ichihara

Tokyo Women's Medical University

Hidenobu Okuda

Moriguchi Keijinkai Hospital

\section{Research Article}

Keywords: Atherosclerosis, Prognosis, Cardiovascular event, Malignant disease, Renin-angiotensin system, (Pro)renin receptor

Posted Date: April 6th, 2021

DOI: https://doi.org/10.21203/rs.3.rs-379462/v1

License: (우 This work is licensed under a Creative Commons Attribution 4.0 International License. Read Full License 


\section{Abstract}

The (pro)renin receptor $[(P) R R)]$ is a multifunctional protein that is cleaved to generate the soluble $(P) R R$ $[s(P) R R]$, reflecting the status of the tissue renin-angiotensin system and/or activity of the (P)RR. The serum $s(P) R R$ level is associated with arteriosclerosis, independent of other risk factors, in patients undergoing hemodialysis (HD). This study was conducted to investigate whether the $s(P) R R$ level was associated with new-onset cardiovascular events or malignant diseases and poor prognosis in patients undergoing HD. Overall, 258 patients [70 (61-76) years, 146 males] undergoing maintenance HD were prospectively followed up for 60 months. We investigated the relationships between s(P)RR levels and new-onset cardiovascular events/ malignant diseases and mortality during the follow-up period using Cox proportional hazard analyses. The cumulative incidence of new-onset cardiovascular events $(P=0.009)$ and deaths $(P<$ $0.001)$, but not of malignant diseases, was significantly greater in patients with higher serum $s(P) R R$ level $(\geq 29.8 \mathrm{ng} / \mathrm{ml})$ than in those with lower $\mathrm{s}(\mathrm{P})$ RR level $(<29.8 \mathrm{ng} / \mathrm{ml})$. A high serum s(P)RR level was independently correlated with cardiovascular mortality $(95 \% \mathrm{Cl} 1.001-1.083, \mathrm{P}=0.046)$. The serum s(P)RR level was associated with cardiovascular events and mortality, thus qualifying as a biomarker for identifying patients requiring intensive care.

\section{Introduction}

The (pro)renin receptor [(P)RR], a specific receptor for renin and prorenin, consists of 350 amino acids with a single transmembrane domain and preferentially binds to renin and prorenin. ${ }^{1}$ It is widely expressed in various organs, such as the brain, heart, and kidneys. ${ }^{2,3}$ Non-proteolytic renin activation by the binding of prorenin to the extracellular domain of $(\mathrm{P}) \mathrm{RR}^{4}$ accelerates the conversion of angiotensinogen to angiotensin (Ang) I. This mechanism has been proposed as a source of renin activity in the tissue renin-angiotensin system. ${ }^{1}$ The soluble form of PRR[s(P)RR] is generated by intracellular cleavage by processing enzymes and is secreted into the extracellular space and found in the blood. These findings suggest that $s(P) R R$ can serve as a biomarker that reflects the status of the tissue RAS and/or (P)RR activity. ${ }^{5,6}$ Moreover, $(P) R R$ is a multi-functioning protein that allows local production of Ang I from angiotensinogen and induces intracellular signals independent of RAS activation.

It was recently discovered that $(P) R R$ also functions as an adaptor protein between the Wnt receptor complex and vacuolar proton-translocating adenosine triphosphatase (V-ATPase). ${ }^{7}$ (P) RR- and V-ATPasemediated acidification was shown to be essential for the Wnt/ $\beta$-signaling pathway, ${ }^{7}$ which is implicated in stem-cell biology and human diseases, including cancer, and has important roles in embryonic development, such as in axis formation and the patterning of the central nervous system. ${ }^{8-10}$ Recently, accumulating evidence has revealed that overexpression of $(P) R R$, which may contribute to cancer initiation and progression, has been observed in various cancers including breast carcinoma, ${ }^{11}$ pancreatic ductal adenocarcinoma, ${ }^{12}$ glioma, ${ }^{13}$ and aldosterone-producing adenoma. ${ }^{14}$ Patients undergoing hemodialysis (HD) have a poor prognosis because of the increased prevalence of cardiovascular diseases (CVD) in this population. ${ }^{15,16}$ Patients with heart failures have significantly higher plasma $s(P) R R$ levels than control subjects. ${ }^{17}$ We previously reported that the serum s(P)RR level was associated with arteriosclerosis, 
independent of other risk factors, in patients undergoing $H D,{ }^{18}$ and the high serum $\mathrm{s}(\mathrm{P}) \mathrm{RR}$ level was associated with increases in brain natriuretic peptide (BNP), a marker of left ventricular dysfunction, ${ }^{19}$ independent of other risk factors. These suggested that the increased expression of (P)RR may be associated with the progression of heart failure in patients undergoing $\mathrm{HD} .{ }^{20}$ Furthermore, it has been reported that patients undergoing $\mathrm{HD}$ are at a high risk for malignant diseases. ${ }^{21,22}$ However, whether the blood s(P)RR levels are associated with the development of cardiovascular events or malignant diseases in patients undergoing HD has not been reported. Furthermore, it remains undetermined whether the blood $s(P) R R$ level is related to total deaths and/or cardiovascular deaths in patients undergoing HD. On the basis of these background findings and unresolved questions, the present study aimed to investigate whether the serum $s(P) R R$ level was associated with new-onset cardiovascular events or malignant diseases and with prognosis in patients undergoing HD during a follow-up period of 60 months.

\section{Methods}

\section{Study subjects}

The participants were outpatients on maintenance HD at the Kadoma Keijinnkai Clinic, Neyagawa Keijinnkai Clinic, and Moriguchi Keijinnkai Clinic in Osaka Prefecture, Japan, in April 2014. All three clinics are affiliated with the Moriguchi Keijinkai Hospital, Osaka, Japan. This study was approved by the ethics committee of Tokyo Women's Medical University (approval number: 2703) and was conducted in accordance with principles of the 1975 Declaration of Helsinki, as revised in 2013. All patients were enrolled after they provided written informed consent. A total of 258 patients undergoing maintenance HD, who were enrolled in our previous cohort study that investigated the relationships between serum s(P)RR levels and background factors, ${ }^{18}$ were prospectively followed up for 60 months. Each patient underwent HD therapy thrice a week for 3-4 hours at the same time each day.

\section{Background factors}

At the start of this study, we collected information on the study population, including age, sex, body mass index (BMI), primary disease (the presence or absence of diabetes mellitus), duration of HD, smoking status, past history of cardiovascular events and malignant diseases, urine volume ( $\geq 0 \mathrm{ml} /$ day), and consumption of selected medications. BMI was calculated as follows: BMI = \{post-dialysis body weight $(\mathrm{kg}) /$ [height $(m) f^{R} \times 100$. Five systolic blood pressure (SBP) values were measured on the 1 st dialysis day of the week: the first was SBP at the start of dialysis; the second and third were the highest and lowest SBP during dialysis, respectively; the fourth was the difference between the highest and lowest values; the fifth was SBP at the end of dialysis. The post-dialysis cardiothoracic ratio (CTR) values were obtained on the $1 \mathrm{st}$ dialysis day of the week. The normalized dialysis dose $(\mathrm{Kt} / \mathrm{V})$ was calculated on the 1 st dialysis day of the week using the following equation, i.e., the formula of Daugirdas ${ }^{23}: \mathrm{Kt} / \mathrm{V}=-\operatorname{Ln}\{[($ post-dialysis value of blood urea nitrogen $(B U N) /$ pre-dialysis value of BUN $)-(0.008 \times$ dialysis time $)]+[4-(3.5 \times$ post-dialysis value of BUN/pre-dialysis value of BUN)] x (amount of drainage/post-dialysis body weight)\}.

\section{Blood examinations}


Non-fasting blood samples were obtained while patients were lying in bed in a supine position after at least 15 minutes of rest on the 1 st dialysis day of the week. The following pre-dialysis parameters were measured: hemoglobin $(\mathrm{Hb})$, high-density lipoprotein cholesterol, low-density lipoprotein cholesterol, triglyceride (TG), albumin-corrected calcium, inorganic phosphorus, intact parathyroid hormone, plasma renin activity, plasma aldosterone concentration, aldosterone to renin ratio, $\mathrm{HbA} 1 \mathrm{c}$, and creatinine (Cre), uric acid, C-reactive protein (CRP), and albumin (Alb) levels. Pre-dialysis serum s(P)RR levels were measured using an enzyme-linked immunosorbent assay (ELISA) kit (Takara Bio Inc., Otsu City, Japan) consisting of a solid-phase sandwich ELISA with highly specific antibodies for each protein. ${ }^{24}$

The following post-dialysis values were measured using conventional methods at an external testing laboratory (Kishimoto, Inc., Tomakomai City, Japan): human atrial natriuretic peptide (hANP), a marker of body fluid volume $\mathrm{e}^{25,26,27}$ and BNP.

\section{Physiological function tests}

\section{Echocardiography}

Echocardiography was performed on a non-dialysis day, as previously described, ${ }^{28}$ using the Vivid S6 System (GE Healthcare, Milwaukee, WI, USA), and cardiac functions were estimated as follows: 1) left ventricular ejection fraction, as a marker of contractile activity; 2) left ventricular mass index, as a marker of cardiac hypertrophy ${ }^{29}$; and 3) $\mathrm{E} / \mathrm{e} \mathbb{Z}$ and deceleration time, as markers of left ventricular diastolic function. ${ }^{30}$

\section{Carotid intima-media thickness}

Ultrasonographic examinations of the common carotid artery, bulb, and internal carotid artery were bilaterally performed on a non-dialysis day, as described previously, ${ }^{31}$ using the Nemio 30 Ultrasound System (Toshiba Medical Systems Co., Ltd, Tochigi, Japan).

\section{Ankle-brachial index and brachial-ankle pulse wave velocity}

The ankle-brachial index (ABI) (average and lower values) and brachial-ankle pulse wave velocity (baPWV) values (average and higher values) were measured on a non-dialysis day using a volume-plethysmographic apparatus PWV/ABI (Omron Healthcare Co., Ltd., Kyoto, Japan) following previously described methods. ${ }^{32}$ The BaPWV cannot be properly estimated when the $A B I$ is lower than 0.9 because arterial occlusion retards the baPWV. ${ }^{33,34}$ Therefore, patients with $\mathrm{ABI}<0.9$ were excluded from the baPWV analysis.

\section{Computed tomography}

Body fat distribution was determined on a non-dialysis day using computed tomography (CT) imaging with a 64-row multislice CT scanner (Aquilion 64; Toshiba, Tokyo, Japan). The subcutaneous and visceral fat areas were measured at the level of the umbilicus using the Ziostation 2 software (Ziosoft, Tokyo, Japan).

New-onset cardiovascular events or malignant diseases 
The occurrence of cardiovascular events or malignant diseases was investigated by either verifying with the electronic medical record for patients who had been undergoing dialysis at our affiliated clinic for five years or through telephone or letter. Cardiovascular events were defined as 1) cardiovascular death, 2) nonfatal myocardial infarction, 3) unstable angina, 4) heart failure, 5) cerebral infarction or cerebral hemorrhage, and 6) severe lower limb ischemia (severe arteriosclerosis obliterans). Malignant diseases include stomach, colorectal, small intestinal, lung, renal, bladder, ureteral, penile, laryngeal, thyroid gland, and breast cancers, uterine neoplasms, and malignant melanomas.

\section{Study protocols}

The pre-dialysis serum s(P)RR levels on the 1st dialysis day of the week were measured at the start of the study. The patients were divided into two groups (higher and lower groups) according to the serum s(P)RR values, and the two groups were compared in terms of background factors and blood, physiological function, and CT data. Patients were followed up for 60 months or until death from any cause, and the relationship between serum $s(P) R R$ levels and new-onset cardiovascular events or malignant diseases was investigated using annual physiological tests, such as abdominal echo and CT imaging. In addition, the association between serum s(P)RR values and all-cause, cardiovascular, and non-cardiovascular mortalities was investigated between the two groups.

\section{Statistical analyses}

Normally distributed continuous variables are expressed as means \pm standard deviations and non-normally distributed ones as medians with interquartile ranges (25th and 75th percentiles). Intergroup comparisons of parameters were performed using the Wilcoxon signed-rank or Mann-Whitney $U$ test. Categorical variables are presented as the number of patients and compared using the chi-square test. Kaplan-Meier plots and log-rank tests were also used to compare the all-cause, cardiovascular, and non-cardiovascular mortalities between the two groups (higher versus lower serum s(P)RR values). The $\mathrm{C}$-index and area under the curve values were used to evaluate the effects of specific variables on survival. ${ }^{35}$ Background factors contributing to cardiovascular mortality were analyzed using univariate Cox proportional hazard regression. In addition, we constructed multivariate Cox proportional hazard regression models to estimate the hazard ratios $(\mathrm{HR})$ and $95 \%$ confidence intervals $(95 \% \mathrm{Cl})$ for cardiovascular mortality using factors showing significant correlations as covariates with mortality. The level of significance was set at $P<0.05$. All analyses were performed using the Bell Curve for Excel (Social Survey Research Information Co. Ltd., Tokyo, Japan).

\section{Results}

\section{Characteristics of the study patients at baseline}

All 255 patients, excluding three who received renal transplants during the study period, could be consecutively followed up for 60 months or until death [60 (38-60)]. The median serum s(P)RR value of these patients at baseline was $29.8 \mathrm{ng} / \mathrm{ml}$. Table 1 details the baseline characteristics of the study patients in the two groups (higher group, serum s(P)RR level $\geq 29.8 \mathrm{ng} / \mathrm{ml}$; lower group, $<29.8 \mathrm{ng} / \mathrm{ml}$ ) and includes 
background factors and blood, physiological function, and CT data. The number of patients with $A B I$ measurements was 247 (96.9\%). ABI was $<0.9$ in 44 patients and as a result 203 patients underwent the baPWV analysis. When comparing between higher and lower groups of serum $s(P) R R$ concentration, the $\mathrm{CTR}, \mathrm{Hb}, \mathrm{TG}$, and CRP levels were significantly greater, and the highest and lowest SBP values and those at the beginning and end of the dialysis were significantly smaller in the higher group than in the lower group. The percentage of patients taking RAS-inhibitors (RAS-Is), such as angiotensin receptor blockers, angiotensin-converting enzyme inhibitors, and renin inhibitors, was significantly greater in the lower group than in the higher group (83.7\% vs. $69.0 \%$ ). Primary disease (presence or absence of diabetes mellitus) was not significantly different between the two groups. In addition, the BMI and Kt/V did not significantly differ between the two groups, suggesting that HD parameters may not strongly influence the serum $\mathrm{s}(\mathrm{P}) \mathrm{RR}$ levels. There were $121(47.4 \%)$ patients with a past history of cardiovascular events; $13(4.7 \%)$ had nonfatal myocardial infarction, 41 (16.1\%) unstable angina, 29 (11.4\%) heart failure, $56(22.0 \%)$ cerebral infarction or cerebral hemorrhage, and 14 (5.5\%) severe lower limb ischemia (severe arteriosclerosis obliterans). There were $27(10.6 \%)$ patients with a past history of multiple cardiovascular events. Thirty-nine patients (15.1\%) had a past history of malignant diseases; 10 (3.9\%) had stomach cancer, eight (3.1\%) colorectal cancer, one $(0.4 \%)$ small intestinal cancer, four (1.6\%) lung cancer, six (2.3\%) renal cancer, four (1.6\%) bladder cancer, one $(0.4 \%)$ ureteral cancer, one $(0.4 \%)$ penile cancer, one $(0.4 \%)$ laryngeal cancer, one $(0.4 \%)$ thyroid gland cancer, three (1.2\%) breast cancer, one $(0.4 \%)$ uterine neoplasm, and one $(0.4 \%)$ malignant melanoma. There were two patients $(0.8 \%)$ with a past history of multiple malignant diseases. The ratios of the past histories of cardiovascular events and malignant diseases were not significantly different between the groups.

\section{Estimating the risk of new-onset cardiovascular events}

During the 60-month follow-up period, 115 patients recorded new-onset cardiovascular events; 27 died of cardiovascular causes (23.5\%), 5 had nonfatal myocardial infarction (4.3\%), 26 unstable angina (22.6\%), 12 heart failure (10.4\%), 24 cerebral infarction or cerebral hemorrhage (20.9\%), and 21 severe lower limb ischemia (severe arteriosclerosis obliterans) $(18.3 \%)$. The serum $\mathrm{s}(\mathrm{P}) \mathrm{RR}$ levels were significantly higher in patients with new-onset cardiovascular events $(31.2 \pm 6.1 \mathrm{ng} / \mathrm{ml}, \mathrm{n}=115)$ than in those without them $(29.8$ $\pm 6.1 \mathrm{ng} / \mathrm{ml}, \mathrm{n}=140) ; P=0.039$. The serum $\mathrm{s}(\mathrm{P})$ RR levels in patients who developed severe lower limb ischemia were particularly high (Table 2). The incidence of new-onset cardiovascular events at the end of the follow-up period was significantly higher in patients with higher serum $s(P)$ RR levels $(52.8 \%)$ than in those with lower serum $s(P) R R$ levels $(38.3 \%) ; P=0.010$. The cumulative incidence of new-onset cardiovascular events was significantly greater in patients with higher serum $s(P) R R$ concentrations than in those with lower s(P)RR concentrations (Figure 1).

\section{Estimating the risk of new-onset malignant diseases}

During the 60-month follow-up period, 38 patients recorded new-onset malignant diseases. At the end of the follow-up period, the serum $s(P) R R$ levels did not significantly differ between patients with new-onset malignant diseases [30.5 (26.5-34.4) $\mathrm{ng} / \mathrm{ml}, \mathrm{n}=38$ ] and those without $(30.4 \pm 6.2 \mathrm{ng} / \mathrm{ml}, \mathrm{n}=217) ; \mathrm{P}=$ 0.420. There was no difference in serum $s(P) R R$ levels depending on the malignant-disease type (Table 3$)$. 
There was no difference in the incidence of new-onset malignant diseases between patients with higher serum s(P)RR levels (16.5\%) and those with lower levels (15.6\%); $P=0.422$.

\section{Association between serum $\mathrm{s}(\mathrm{P}) \mathrm{RR}$ levels and prognosis}

During the 60-month follow-up period, 106 deaths (41.6\%) were recorded, including 63 cardiovascular deaths (24.7\%) -2 due to acute myocardial infarction, 27 due to congestive heart failure, 15 due to lethal arrhythmia, and 6 due to cerebral hemorrhage, and 13 sudden unexpected deaths. Forty-three noncardiovascular deaths (16.9\%) were recorded -15 due to infectious diseases, 21 due to cachexia, 5 due to cancer, and 2 due to liver failure. The 1-year, 2-year, 3-year, 4-year, and 5-year survival rates were $91.8 \%$, $85.5 \%, 76.1 \%, 69.0 \%$, and $58.0 \%$, respectively. At the end of the follow-up period, the serum s(P)RR levels were significantly higher in patients who died by any cause $(31.8 \pm 5.8 \mathrm{ng} / \mathrm{ml}, \mathrm{n}=106)$ and in those who died of cardiovascular causes $(32.5 \pm 6.5 \mathrm{ng} / \mathrm{ml}, \mathrm{n}=63)$ than in those who survived $(29.5 \pm 6.3 \mathrm{ng} / \mathrm{ml}, \mathrm{n}=$ 149 and $29.7 \pm 5.8 \mathrm{ng} / \mathrm{ml}, \mathrm{n}=192$, respectively; $\mathrm{P}=0.005,<0.001$, respectively). The higher serum $\mathrm{s}(\mathrm{P}) \mathrm{RR}$ group had higher rates of total $(49.6 \%)$ and cardiovascular $(33.9 \%)$ deaths than the lower serum $s(P) R R$ group (total: $33.6 \%$ and cardiovascular: $15.6 \%$, respectively) $(P=0.005$ and $P<0.001$, respectively).

Kaplan-Meier analyses showed that the cumulative survival rate of total death in the higher serum s(P)RR group was not significantly lower than that in the lower group (log-rank test, $\chi 2=3.0, P=0.083$ ), but the cumulative survival rate of cardiovascular death in the higher group was significantly lower than that in the lower group (log-rank test, $\chi 2=11.1, P<0.001$ ) (Figure 2). A receiver operating characteristic curve was constructed to determine the optimal cutoff value of the serum $s(P) R R$ level for cardiovascular death (Figure 3). The optimal cutoff value of the serum s(P)RR level for cardiovascular death was $29.4 \mathrm{ng} / \mathrm{ml}$ (sensitivity, 0.778; specificity, 0.526) (Figure 3). Univariate Cox regression analyses showed that age, primary disease (diabetes mellitus) status; the difference (the highest - the lowest) in SBP values; medications (statin); CTR, s(P)RR, TG, hANP, BNP, and HbA1c values; max carotid intima-media thickness; and baPWV (average and higher values) were significantly and positively correlated while SBP (highest values), SBP (lowest values), SBP values at the end, medications (RAS-I), medications (calcium channel blockers), Cre, Alb, and ABI (average and lower values) were significantly and negatively correlated with cardiovascular death (Table 4). The results of the multivariate Cox regression analyses for cardiovascular mortality are shown in Table 5. All factors that were significantly correlated with total death in the univariate analyses (Table 4) were used as covariates in model 1. Factors that correlated with cardiovascular death, excluding $A B I$ and baPWV, were used as covariates in model 2. Although the $s(P) R R$ level was not significantly correlated with cardiovascular death in model 1 , it showed a significant positive relationship with cardiovascular death in model 2 (HR: $1.041,95 \% \mathrm{Cl}: 1.001-1.083, \mathrm{P}=0.046$ ).

\section{Discussion}

The present study investigated the relationship between high serum s(P)RR levels and the occurrence of cardiovascular events or malignant diseases and the prognosis in patients undergoing HD; the study produced three major findings. First, the CTR, Hb, TG, and CRP levels were significantly higher, and several SBP values were significantly lower in the higher serum $s(P) R R$ group than in the lower serum s(P)RR group. 
Second, the occurrence ratio of cardiovascular events was significantly higher in the higher serum $s(P) R R$ group than in the lower serum $s(P) R R$ group. Finally, the serum $s(P) R R$ level was independently associated with cardiovascular mortality, suggesting that increased expression of $(P) R R$ may be associated with the progression of cardiovascular events in patients undergoing HD.

In the present study, atherogenic factors, such as the CTR, TG, and CRP levels, were found to be greater in the higher serum $s(P) R R$ group than in the lower serum $s(P) R R$ group (Table 1) in accordance with the findings of our previous report. ${ }^{18}$

We previously reported that the serum $s(P) R R$ level was associated with atherosclerosis, independent of other risk factors, in patients undergoing $H D,{ }^{18}$ and a high serum $s(P) R R$ level was associated with an increase in BNP, independent of other risk factors. ${ }^{20}$ From a clinical perspective, these considerations suggest that patients with elevated $s(P) R R$ concentrations should be screened for CVD risk factors. Conversely, there was no difference between the higher and lower $s(P) R R$ groups with respect to their past histories of CVD or malignant diseases (Table 1). These results suggest that the serum s(P)RR concentration at the time of measurement may not be affected by the past history of cardiovascular events or malignant diseases.

In this study, the serum s(P)RR levels were significantly higher in patients who experienced cardiovascular events during the follow-up period than in patients who did not; vice versa the incidence of cardiovascular events was significantly higher in patients with higher serum s(P)RR levels than in those with lower serum $s(P)$ RR levels (Figure 1). We previously reported that high serum $s(P)$ RR levels in patients undergoing HD were associated with severe atherosclerosis of the lower limbs, independent of other risk factors. ${ }^{18}$ Therefore, we considered it is possible that serum $s(P) R R$ could be used as a marker for atherosclerotic conditions. We also reported that a high serum $s(P) R R$ level was associated with an increase in BNP during the first 1-year follow-up period, independent of other risk factors, ${ }^{20}$ suggesting that increased expression of (P)RR may be associated with the progression of heart failure in patients undergoing HD. Accordingly, higher $\mathrm{s}(\mathrm{P}) \mathrm{RR}$ levels may be associated with increased occurrence of cardiovascular events in patients undergoing $H D$, and serum $s(P) R R$ could be potentially used as a predictive marker for cardiovascular events in these patients.

(P)RR acts as an adaptor protein that co-locates with the Wnt receptor complex and contributes to the activation of Wnt/ $\beta$-catenin signaling, independent of RAS. ${ }^{7}$ The Wnt/ $\beta$-catenin signaling pathway plays a pivotal role in numerous biological processes, such as in embryonic development, tissue homeostasis, and carcinogenesis. ${ }^{8}$ Overexpression of (P)RR has been observed in various malignant diseases, including pancreatic, ${ }^{12,36}$ brain, ${ }^{13,37}$ colorectal, ${ }^{38,39}$ breast $^{11}$ adrenal, ${ }^{14}$ and endometrial ${ }^{40}$ cancers. Overexpression of (P)RR may contribute to cancer initiation and progression via the $W n t / \beta$-catenin, RAS, mitogen-activated protein kinase/extracellular signal-regulated kinase (ERK), and phosphatidylinositol 3-kinase-protein kinase/protein kinase B/mammalian target of rapamycin pathways, as well as to V-ATPase function in various cancers. ${ }^{41}$ 
Patients undergoing HD are at a high risk for malignant diseases in the kidneys, bladder, thyroid, and other endocrine organs. ${ }^{21,22}$ Although the reason for the increased risk of malignant diseases in patients undergoing HD remains unclear, there are several possible explanations, including chronic inflammation, inhibition of the immune system, ${ }^{42}$ poor nutritional status, reduced antioxidant capacity, accumulation of carcinogens, ${ }^{43}$ and dialysis-related factors. ${ }^{44}$ In the present study, however, there was no difference in the incidence of malignant diseases between patients with higher and lower serum s(P)RR levels (Table 3). The possible reasons for this lack of association between $s(P) R R$ concentration and cancer are insufficient sample size and limited follow-up. Besides, we cannot exclude the possibility of other confounding factors that affect the occurrence of malignant diseases in patients undergoing HD masking the effects of $(P) R R$. This issue should be addressed in further investigations.

Chronic kidney disease (CKD) is associated with the risk of developing CVD, ${ }^{45}$ and the risk of total death, cardiovascular death, and hospitalization due to CVDs is high in patients with CKD. ${ }^{46}$ In keeping with these data, the present study showed high all-cause mortality (41.6\%) and high cardiovascular mortality (24.7\%) in patients undergoing HD during the 60-month follow-up period. In patients undergoing HD, age, primary disease (diabetes mellitus) status, intradialytic BP change ${ }^{47}$ intradialytic hypotension, ${ }^{48}$ serum Alb level, ${ }^{49}$ and medication (RAS-I) ${ }^{50}$ are, in general, associated with prognosis. In line with these reports, our study showed that age, primary disease (diabetes mellitus) status, and intradialytic BP change were significantly and positively correlated and the lowest intradialytic BP, medications (RAS-Is), and Alb level were significantly and negatively correlated with cardiovascular deaths (Table 4). Although the cumulative survival rate of cardiovascular death in the higher $s(P) R R$ group was significantly lower than that in the lower $s(P) R R$ group (Figure 2), the difference was not apparent until 20 months after the initiation of the study. The reason for this remains unclear; however, as the two groups had similar cardiac functions, carotid intima-media thicknesses, $\mathrm{ABI}$ and baPWV values, and histories of CVD at the start of this study, sufficient time may have been required for the differences to manifest (Table 1).

This study showed for the first time that the $s(P) R R$ level is associated with cardiovascular mortality in patients undergoing HD. Atherosclerosis and vascular calcification have been shown to be risk factors for CVD in patients with CKD. ${ }^{51,52}$ (P)RR-mediated ERK signal transduction, independent of the generation of angiotensin II or the activation of its receptor, contributed to the development of vascular complications. ${ }^{53,54}$ The serum s(P)RR concentration was associated with arteriosclerosis ${ }^{18}$ and worsening of heart failure. ${ }^{20}$ We also showed that the long-term administration of a (P)RR blocker attenuated the development of cardiac fibrosis and hypertrophy. ${ }^{55}$ Therefore, although the mechanism by which the blood $s(P) R R$ concentration is associated with cardiovascular mortality remains unclear, we suppose that a high $s(P) R R$ concentration could be associated with cardiovascular mortality via increased tissue (P)RR expression and atherosclerosis and/or heart failure and subsequent cardiovascular events. Further studies are required to test this assumption.

Several limitations of the present study warrant mention. First, our sample size was relatively small. Second, the present data from patients undergoing HD may have been modulated by HD therapy because $s(P) R R$ may have been dialyzed to some extent. ${ }^{14}$ Third, the mechanisms by which the serum $s(P) R R$ level 
is associated with background factors remain unclear. Further studies are required to clarify the role of serum $s(P) R R$ in patients undergoing $H D$.

In conclusion, high serum $s(P) R R$ level in patients undergoing HD was associated with various background factors and the occurrence of cardiovascular events. Furthermore, a high serum $s(P) R R$ level was independently correlated with cardiovascular mortality. Therefore, $s(P) R R$ could potentially be used as a marker for the occurrence of cardiovascular events and cardiovascular mortality and thus, could be useful in selecting patients requiring intensive care. Further studies are needed to determine whether reducing the serum $s(P) R R$ level would improve patient prognosis in this population.

\section{Declarations}

\section{Acknowledgments}

We would like to thank Noriko Morishima and Chinami Muramatsu for their technical support during the $s(P) R R$ assay. This work was supported in part by grants from the Ministry of Education, Culture, Sports, Science, and Technology of Japan ( 19 K 08497 to S. M.). We would also like to thank Editage (www.editage.com) for English language editing.

\section{Author contributions}

S.M. and A.I. designed the study; Y.A., C.S., T.I., H.O., T.Y., Y.O., N.A., and F.N. collected the data; Y.A. and S.M. analyzed the data; Y.A. and S.M. prepared the figures; Y.A., S.M., and A.I. drafted and revised the paper. All authors approved the final version of the manuscript.

\section{Disclosures}

There is no conflict of interest that was perceived to prejudice the impartiality of the research reported.

\section{References}

1 Nguyen, G. et al. Pivotal role of the renin/prorenin receptor in angiotensin II production and cellular responses to renin. J Clin Invest 109, 1417-1427, doi:10.1172/JCl14276 (2002).

2 Hirose, T. et al. Gene expression of (pro)renin receptor is upregulated in hearts and kidneys of rats with congestive heart failure. Peptides 30, 2316-2322, doi:10.1016/j.peptides.2009.09.015 (2009).

3 Takahashi, K. et al. Expression of (pro)renin receptor in the human brain and pituitary, and colocalisation with arginine vasopressin and oxytocin in the hypothalamus. $J$ Neuroendocrinol 22, 453-459, doi:10.1111/j.1365-2826.2010.01980.x (2010).

4 Suzuki, F. et al. Human prorenin has "gate and handle" regions for its non-proteolytic activation. $J$ Biol Chem 278, 22217-22222, doi:10.1074/jbc.M302579200 (2003). 
$5 \quad$ Watanabe, N. et al. Prediction of gestational diabetes mellitus by soluble (pro)renin receptor during the first trimester. J Clin Endocrinol Metab 98, 2528-2535, doi:10.1210/jc.2012-4139 (2013).

6 Morimoto, S. et al. Serum soluble (pro)renin receptor levels in patients with essential hypertension. Hypertens Res 37, 642-648, doi:10.1038/hr.2014.46 (2014).

7 Cruciat, C. M. et al. Requirement of prorenin receptor and vacuolar H+-ATPase-mediated acidification for Wnt signaling. Science 327, 459-463, doi:10.1126/science.1179802 (2010).

8 Logan, C. Y. \& Nusse, R. The Wnt signaling pathway in development and disease. Annu Rev Cell Dev Bio/ 20, 781-810, doi:10.1146/annurev.cellbio.20.010403.113126 (2004).

$9 \quad$ Polakis, P. Wnt signaling and cancer. Genes Dev 14, 1837-1851 (2000).

10 Clevers, H. Wnt/beta-catenin signaling in development and disease. Cel/ 127, 469-480, doi:10.1016/j.cell.2006.10.018 (2006).

11 Ohba, K. et al. Expression of (pro)renin receptor in breast cancers and its effect on cancercell proliferation. Biomed Res 35, 117-126, doi:10.2220/biomedres.35.117 (2014).

12 Shibayama, Y. et al. (Pro)renin receptor is crucial for Wnt/beta-catenin-dependent genesis of pancreatic ductal adenocarcinoma. Sci Rep 5, 8854, doi:10.1038/srep08854 (2015).

13 Kouchi, M. et al. (Pro)renin receptor is crucial for glioma development via the Wnt/beta-catenin signaling pathway. J Neurosurg 127, 819-828, doi:10.3171/2016.9.JNS16431 (2017).

14 Yamamoto, H. et al. Increased expression of (pro)renin receptor in aldosterone-producing adenomas. Peptides 49, 68-73, doi:10.1016/j.peptides.2013.08.022 (2013).

15 Levey, A. S. et al. Controlling the epidemic of cardiovascular disease in chronic renal disease: what do we know? What do we need to learn? Where do we go from here? National Kidney Foundation Task Force on Cardiovascular Disease. Am J Kidney Dis 32, 853-906, doi:10.1016/s0272-6386(98)70145-3 (1998).

16 Iseki, K. Role of chronic kidney disease in cardiovascular disease: are we different from others? Clin Exp Nephrol 15, 450-455, doi:10.1007/s10157-011-0439-8 (2011).

17 Fukushima, A. et al. Increased plasma soluble (pro)renin receptor levels are correlated with renal dysfunction in patients with heart failure. Int J Cardio/ 168, 4313-4314, doi:10.1016/j.ijcard.2013.04.176 (2013).

18 Amari, Y., Morimoto, S., Nakajima, F., Ando, T. \& Ichihara, A. Serum Soluble (Pro)Renin Receptor Levels in Maintenance Hemodialysis Patients. PLoS One 11, e0158068, doi:10.1371/journal.pone.0158068 (2016). 
19 Atisha, D. et al. A prospective study in search of an optimal B-natriuretic peptide level to screen patients for cardiac dysfunction. Am Heart J 148, 518-523, doi:10.1016/j.ahj.2004.03.014 (2004).

20 Amari, Y. et al. Association between serum soluble (pro)renin receptor level and worsening of cardiac function in hemodialysis patients: A prospective observational study. PLoS One 15, e0233312, doi:10.1371/journal.pone.0233312 (2020).

21 Maisonneuve, P. et al. Cancer in patients on dialysis for end-stage renal disease: an international collaborative study. Lancet 354, 93-99, doi:10.1016/s0140-6736(99)06154-1 (1999).

22 Chien, C. C. et al. Epidemiology of cancer in end-stage renal disease dialysis patients: a national cohort study in Taiwan. J Cancer 8, 9-18, doi:10.7150/jca.16550 (2017).

23 Daugirdas, J. T. Second generation logarithmic estimates of single-pool variable volume Kt/V: an analysis of error. J Am Soc Nephrol 4, 1205-1213 (1993).

24 Maruyama, N., Segawa, T., Kinoshita, N. \& Ichihara, A. Novel sandwich ELISA for detecting the human soluble (pro)renin receptor. Front Biosci (Elite Ed) 5, 583-590 (2013).

25 Kuwahara, M. et al. [Clinical significance of HANP (human atrial natriuretic peptide) in patients on maintenance hemodialysis-HANP as a parameter to determine the dry weight (D.W.)]. Hinyokika Kiyo 38, 58 (1992).

26 Metry, G. et al. Fluid balance in patients with chronic renal failure assessed with N-terminal proatrial natriuretic peptide, atrial natriuretic peptide and ultrasonography. Acta Physiol Scand 171, 117-122, doi:10.1046/j.1365-201x.2001.00792.x (2001).

27 Plum, J. et al. Comparison of body fluid distribution between chronic haemodialysis and peritoneal dialysis patients as assessed by biophysical and biochemical methods. Nephrol Dial Transplant 16, 23782385, doi:10.1093/ndt/16.12.2378 (2001).

28 van Eps, C. L. et al. Cardiac and vascular structure and function parameters do not improve with alternate nightly home hemodialysis: an interventional cohort study. BMC Nephro/ 12, 51, doi:10.1186/1471-2369-12-51 (2011).

29 Zoccali, C. et al. Prognostic impact of the indexation of left ventricular mass in patients undergoing dialysis. J Am Soc Nephrol 12, 2768-2774 (2001).

30 Ommen, S. R. \& Nishimura, R. A. A clinical approach to the assessment of left ventricular diastolic function by Doppler echocardiography: update 2003. Heart 89 Suppl 3, iii18-23, doi:10.1136/heart.89.suppl_3.iii18 (2003).

31 Yurugi, T. et al. Accumulation of visceral fat in maintenance hemodialysis patients. Clin Exp Nephrol 16, 156-163, doi:10.1007/s10157-011-0544-8 (2012). 
32 Yamashina, A. et al. Validity, reproducibility, and clinical significance of noninvasive brachial-ankle pulse wave velocity measurement. Hypertens Res 25, 359-364, doi:10.1291/hypres.25.359 (2002).

33 Yokoyama, H. et al. Pulse wave velocity in lower-limb arteries among diabetic patients with peripheral arterial disease. J Atheroscler Thromb 10, 253-258, doi:10.5551/jat.10.253 (2003).

34 Ishida, A. et al. Arterial stiffness, not systolic blood pressure, increases with age in native Papuan populations. Hypertens Res 41, 539-546, doi:10.1038/s41440-018-0047-z (2018).

35 Uno, H., Cai, T., Pencina, M. J., D'Agostino, R. B. \& Wei, L. J. On the C-statistics for evaluating overall adequacy of risk prediction procedures with censored survival data. Stat Med 30, 1105-1117, doi:10.1002/sim.4154 (2011).

36 Arundhathi, A. et al. Prorenin receptor acts as a potential molecular target for pancreatic ductal adenocarcinoma diagnosis. Oncotarget 7, 55437-55448, doi:10.18632/oncotarget.10583 (2016).

37 Juillerat-Jeanneret, L. et al. Renin and angiotensinogen expression and functions in growth and apoptosis of human glioblastoma. Br J Cancer 90, 1059-1068, doi:10.1038/sj.bjc.6601646 (2004).

38 Wang, J. et al. (Pro)renin receptor promotes colorectal cancer through the Wnt/beta-catenin signalling pathway despite constitutive pathway component mutations. Br J Cancer 120, 229-237, doi:10.1038/s41416-018-0350-0 (2019).

39 Beitia, M. et al. (Pro)renin Receptor Expression Increases throughout the Colorectal AdenomaAdenocarcinoma Sequence and It Is Associated with Worse Colorectal Cancer Prognosis. Cancers (Basel) 11, doi:10.3390/cancers11060881 (2019).

40 Delforce, S. J. et al. Expression of renin-angiotensin system (RAS) components in endometrial cancer. Endocr Connect 6, 9-19, doi:10.1530/EC-16-0082 (2017).

41 Wang, J., Nishiyama, A., Matsuyama, M., Wang, Z. \& Yuan, Y. The (pro)renin receptor: a novel biomarker and potential therapeutic target for various cancers. Cell Commun Signal 18, 39, doi:10.1186/s12964-020-0531-3 (2020).

42 Malachi, T. et al. DNA repair and recovery of RNA synthesis in uremic patients. Kidney Int 44, 385389, doi:10.1038/ki.1993.256 (1993).

43 Yanagisawa, H., Manabe, S., Kanai, Y. \& Wada, O. Carcinogenic glutamic acid pyrolysis product in the dialysate of uremic patients treated by continuous ambulatory peritoneal dialysis. Clin Nephro/ 30, 7378 (1988).

44 Akizawa, T., Kinugasa, E. \& Koshikawa, S. Increased risk of malignancy and blood-membrane interactions in uraemic patients. Nephrol Dial Transplant 9 Suppl 2, 162-164 (1994). 
45 Sarnak, M. J. et al. Kidney disease as a risk factor for development of cardiovascular disease: a statement from the American Heart Association Councils on Kidney in Cardiovascular Disease, High Blood Pressure Research, Clinical Cardiology, and Epidemiology and Prevention. Circulation 108, 2154-2169, doi:10.1161/01.CIR.0000095676.90936.80 (2003).

46 Go, A. S., Chertow, G. M., Fan, D., McCulloch, C. E. \& Hsu, C. Y. Chronic kidney disease and the risks of death, cardiovascular events, and hospitalization. N Engl J Med 351, 1296-1305, doi:10.1056/NEJMoa041031 (2004).

$47 \quad$ Lu, J. et al. The relationship between survival rate and intradialytic blood pressure changes in maintenance hemodialysis patients. Ren Fail 39, 417-422, doi:10.1080/0886022X.2017.1305407 (2017).

48 Shoji, T., Tsubakihara, Y., Fujii, M. \& Imai, E. Hemodialysis-associated hypotension as an independent risk factor for two-year mortality in hemodialysis patients. Kidney Int 66, 1212-1220, doi:10.1111/j.1523-1755.2004.00812.x (2004).

49 Iseki, K. et al. Prevalence and determinants of hypertension in chronic hemodialysis patients in Japan. Ther Apher Dial 11, 183-188, doi:10.1111/j.1744-9987.2007.00479.x (2007).

50 Iseki, K. et al. Higher survival rates of chronic hemodialysis patients on anti-hypertensive drugs. Nephron Clin Pract 113, c183-190, doi:10.1159/000232600 (2009).

51 Raggi, P. et al. Cardiac calcification in adult hemodialysis patients. A link between end-stage renal disease and cardiovascular disease? J Am Coll Cardio/ 39, 695-701, doi:10.1016/s0735-1097(01)01781-8 (2002).

52 London, G. M. et al. Arterial media calcification in end-stage renal disease: impact on all-cause and cardiovascular mortality. Nephrol Dial Transplant 18, 1731-1740, doi:10.1093/ndt/gfg414 (2003).

53 Feldt, S., Maschke, U., Dechend, R., Luft, F. C. \& Muller, D. N. The putative (pro)renin receptor blocker HRP fails to prevent (pro)renin signaling. J Am Soc Nephro/ 19, 743-748, doi:10.1681/ASN.2007091030 (2008).

54 Sakoda, M. et al. (Pro)renin receptor-mediated activation of mitogen-activated protein kinases in human vascular smooth muscle cells. Hypertens Res 30, 1139-1146, doi:10.1291/hypres.30.1139 (2007).

55 Ichihara, A. et al. Nonproteolytic activation of prorenin contributes to development of cardiac fibrosis in genetic hypertension. Hypertension 47, 894-900, doi:10.1161/01.HYP.0000215838.48170.0b (2006).

\section{Tables}


Table 1. Comparison of characteristics of the study participants at baseline between the higher and lower serum $s(P) R R$ concentration groups

\begin{tabular}{|c|c|c|c|c|c|c|c|}
\hline & $\begin{array}{l}\text { Higher } \\
\text { group } \\
(\mathrm{n}=129)\end{array}$ & $\begin{array}{l}\text { Lower } \\
\text { group } \\
(\mathrm{n}=129)\end{array}$ & P-value & & $\begin{array}{l}\text { Higher } \\
\text { group } \\
(\mathrm{n}=129)\end{array}$ & $\begin{array}{l}\text { Lower } \\
\text { group } \\
(\mathrm{n}=129)\end{array}$ & P-value \\
\hline $\begin{array}{l}\text { Background } \\
\text { factors }\end{array}$ & & & & $\begin{array}{l}\text { Inorganic } \\
\text { phosphorus (mq/dl) }\end{array}$ & $\begin{array}{l}5.4(4.4- \\
6.0)\end{array}$ & $5.1 \pm$ & 0.064 \\
\hline Age (years) & $\begin{array}{c}72(62- \\
77)\end{array}$ & $\begin{array}{c}68(59- \\
74)\end{array}$ & 0.07 & $\begin{array}{l}\text { Intact } \\
\text { parathyroid } \\
\text { hormone }(\mathrm{pg} / \mathrm{ml})\end{array}$ & $\begin{array}{l}139.0 \\
(84.0- \\
185.0)\end{array}$ & $\begin{array}{l}123.0 \\
(76.0- \\
176.0)\end{array}$ & 0.305 \\
\hline $\begin{array}{l}\text { Sex } \\
\text { (male/female) }\end{array}$ & $71 / 58$ & $75 / 54$ & 0.615 & $\begin{array}{l}\text { Creatinine } \\
\text { (mg/dl) }\end{array}$ & $\begin{array}{l}9.5 \pm \\
2.5\end{array}$ & $9.7 \pm$ & 0.478 \\
\hline $\begin{array}{r}\text { Body mass } \\
\text { index }\left(\mathrm{kg} / \mathrm{m}^{2}\right)\end{array}$ & $\begin{array}{l}21.8 \\
(19.9- \\
24)\end{array}$ & $\begin{array}{l}21.6 \\
(19.4- \\
24.2)\end{array}$ & 0.549 & $\begin{array}{l}\text { Uric acid } \\
\text { (mg/dl) }\end{array}$ & $\begin{array}{l}7.3 \pm \\
1.4\end{array}$ & $7.0 \pm$ & 0.053 \\
\hline $\begin{array}{l}\text { Primary } \\
\text { disease } \\
\text { (DM/non-DM) }\end{array}$ & $55 / 74$ & $68 / 61$ & 0.105 & CRP (mg/dl) & $\begin{array}{l}0.13 \\
(0.05- \\
0.49)\end{array}$ & $\begin{array}{l}0.07 \\
(0.05- \\
0.19)\end{array}$ & $<0.001$ \\
\hline $\begin{array}{l}\text { Duration } \\
\text { of } \\
\text { hemodialysis } \\
\text { therapy } \\
\text { (months) }\end{array}$ & $\begin{array}{c}48(24- \\
84)\end{array}$ & $\begin{array}{c}48(24- \\
72)\end{array}$ & 0.788 & Albumin (g/dl) & $3.7 \pm$ & $\begin{array}{c}3.7(3.5- \\
3.9)\end{array}$ & 0.422 \\
\hline $\begin{array}{l}\text { Smoking } \\
\text { history } \\
\text { (yes/no) }\end{array}$ & $55 / 74$ & $60 / 69$ & 0.531 & hANP (pg/ml) & $\begin{array}{l}48.2 \\
(28.2- \\
78.2)\end{array}$ & $\begin{array}{l}46.7 \\
(31.5- \\
74.9)\end{array}$ & 0.866 \\
\hline $\begin{array}{l}\text { Past } \\
\text { history of } \\
\text { cardiovascular } \\
\text { events } \\
\text { (yes/no) }\end{array}$ & $58 / 71$ & $63 / 66$ & 0.266 & $\mathrm{BNP}(\mathrm{pg} / \mathrm{ml})$ & $\begin{array}{l}136.6 \\
(76.4- \\
287.4)\end{array}$ & $\begin{array}{l}148.9 \\
(74.9- \\
244.5)\end{array}$ & 0.974 \\
\hline $\begin{array}{l}\text { Past } \\
\text { history of } \\
\text { malignant } \\
\text { diseases } \\
\text { (yes/no) }\end{array}$ & $15 / 114$ & $24 / 105$ & 0.059 & PRA (ng/ml) & $\begin{array}{c}1.7(0.8- \\
4.0)\end{array}$ & $\begin{array}{l}2.3(0.8- \\
4.2)\end{array}$ & 0.438 \\
\hline $\begin{array}{l}\text { Urine } \\
\text { volume }(0 \\
\text { ml/day or } \\
\text { more than } 0 \\
\text { ml/day) }\end{array}$ & $39 / 90$ & $28 / 101$ & 0.94 & PAC $(\mathrm{pg} / \mathrm{ml})$ & $\begin{array}{l}8.8(6.6- \\
12.6)\end{array}$ & $\begin{array}{l}7.5(6.5- \\
10.2)\end{array}$ & 0.673 \\
\hline $\begin{array}{l}\text { SBP during } \\
\text { dialysis } \\
\text { (mmHg) }\end{array}$ & & & & ARR (PAC/PRA) & $\begin{array}{c}5.7(2.3- \\
13.0)\end{array}$ & $\begin{array}{c}3.7(2.0- \\
11.7)\end{array}$ & 0.828 \\
\hline $\begin{array}{l}\text { At the } \\
\text { beginning }\end{array}$ & $\begin{array}{c}145 \pm \\
20\end{array}$ & $\begin{array}{l}154 \pm \\
18\end{array}$ & $<0.001$ & HbA1c (\%) & $\begin{array}{l}5.0(4.7- \\
5.5)\end{array}$ & $\begin{array}{l}5.2(4.9- \\
5.7)\end{array}$ & 0.976 \\
\hline $\begin{array}{l}\text { Highest } \\
\text { values }\end{array}$ & $\begin{array}{l}156 \pm \\
21\end{array}$ & $\begin{array}{c}164 \pm \\
20\end{array}$ & $<0.001$ & $\begin{array}{l}\text { Physical function } \\
\text { tests }\end{array}$ & & & \\
\hline $\begin{array}{l}\text { Lowest } \\
\text { values }\end{array}$ & $\begin{array}{r}121 \pm \\
20\end{array}$ & $\begin{array}{r}128 \pm \\
21\end{array}$ & 0.008 & Echocardiography & & & \\
\hline $\begin{array}{l}\text { Difference } \\
\text { (the highest- } \\
\text { the lowest) }\end{array}$ & $\begin{array}{c}32(24- \\
42)\end{array}$ & $\begin{array}{c}30(22- \\
46)\end{array}$ & 0.194 & LVEF (\%) & $\begin{array}{l}67.6 \\
(62.8- \\
72.1)\end{array}$ & $\begin{array}{c}67.2 \\
(63.5- \\
71.5)\end{array}$ & 0.361 \\
\hline At the end & $\begin{array}{r}136 \pm \\
20\end{array}$ & $\begin{array}{l}143 \pm \\
22\end{array}$ & 0.002 & LVMI $\left(\mathrm{g} / \mathrm{m}^{2}\right)$ & $\begin{array}{l}171.1 \\
(144.9- \\
202.7)\end{array}$ & $\begin{array}{c}180.5 \pm \\
50.0\end{array}$ & 0.202 \\
\hline $\begin{array}{l}\text { Medications } \\
\text { (yes/no) }\end{array}$ & & & & $\mathrm{E} / \mathrm{e}^{\prime}$ & $\begin{array}{l}18.0 \\
(14.0- \\
22.1)\end{array}$ & $\begin{array}{l}18.8 \\
(14.9- \\
22.2)\end{array}$ & 0.404 \\
\hline RAS-I & $89 / 40$ & $108 / 21$ & 0.005 & Dec-T & $\begin{array}{c}229.0 \\
(199.8- \\
264.1)\end{array}$ & $\begin{array}{c}231.7 \pm \\
54.1\end{array}$ & 0.817 \\
\hline$\beta$-blocker & $44 / 85$ & $54 / 75$ & 0.217 & $\begin{array}{l}\text { Carotid } \\
\text { ultrasound }\end{array}$ & & & \\
\hline
\end{tabular}




\begin{tabular}{|c|c|c|c|c|c|c|c|}
\hline CCB & $90 / 39$ & $100 / 29$ & 0.188 & $\begin{array}{c}\text { examination } \\
\text { Max carotid } \\
\text { IMT (mm) }\end{array}$ & $\begin{array}{l}0.9(0.7- \\
1.0)\end{array}$ & $\begin{array}{l}0.9(0.7- \\
1.1)\end{array}$ & 0.394 \\
\hline Statin & $17 / 112$ & $18 / 111$ & 0.428 & ABI & & & \\
\hline $\begin{array}{l}\text { Phosphate } \\
\text { binder }\end{array}$ & $106 / 23$ & $106 / 26$ & 0.5 & $\geq 0.9 /<0.9$ & $96 / 25$ & $107 / 19$ & 0.252 \\
\hline CTR (\%) & $\begin{array}{l}53.0 \\
(49.4- \\
55.4)\end{array}$ & $\begin{array}{l}51.7 \pm \\
5.2\end{array}$ & 0.04 & Average values & $\begin{array}{l}1.15 \\
(1.05- \\
1.23)\end{array}$ & $\begin{array}{l}1.17 \\
(1.07- \\
1.24)\end{array}$ & 0.378 \\
\hline $\mathrm{Kt} / \mathrm{V}$ & $\begin{array}{l}1.36 \pm \\
0.26\end{array}$ & $\begin{array}{c}1.34 \pm \\
0.22\end{array}$ & 0.313 & Lower values & $\begin{array}{l}1.13 \\
(0.95- \\
1.20)\end{array}$ & $\begin{array}{l}1.13 \\
(1.00- \\
1.21)\end{array}$ & 0.776 \\
\hline Blood tests & & & & baPWV (cm/s) & & & \\
\hline $\begin{array}{l}\text { Hemoglobin } \\
\text { (g/dl) }\end{array}$ & $\begin{array}{c}10.9 \pm \\
1.0\end{array}$ & $\begin{array}{l}10.7 \\
(10.2- \\
11.2)\end{array}$ & 0.036 & Average values & $\begin{array}{c}1794.8 \\
(1568.4- \\
2065.9)\end{array}$ & $\begin{array}{l}1853.5 \\
(1606.8- \\
2176.8)\end{array}$ & 0.719 \\
\hline $\begin{array}{l}\text { HDL } \\
\text { cholesterol } \\
\text { (mg/dl) }\end{array}$ & $\begin{array}{l}46.0 \\
(38.0- \\
55.0)\end{array}$ & $\begin{array}{c}45.0 \\
(36.0- \\
55.0)\end{array}$ & 0.632 & Higher values & $\begin{array}{l}1907.0 \\
(1639.5- \\
2165.8)\end{array}$ & $\begin{array}{l}1921.0 \\
(1641.5- \\
2234.0)\end{array}$ & 0.774 \\
\hline $\begin{array}{l}\text { LDL } \\
\text { cholesterol } \\
\text { (mg/dl) }\end{array}$ & $\begin{array}{l}91.3 \pm \\
30.5\end{array}$ & $\begin{array}{l}83.0 \\
(64.0- \\
103.0)\end{array}$ & 0.203 & Abdominal CT & & & \\
\hline $\begin{array}{l}\text { Triglycerides } \\
\text { (mg/dl) }\end{array}$ & $\begin{array}{l}96.0 \\
(68.0- \\
136.0)\end{array}$ & $\begin{array}{l}81.0 \\
(55.0- \\
113.0)\end{array}$ & 0.004 & $\begin{array}{l}\text { Subcutaneous } \\
\text { fat area }\left(\mathrm{cm}^{2}\right)\end{array}$ & $\begin{array}{l}110.9 \\
(72.2- \\
171.2)\end{array}$ & $\begin{array}{l}105.5 \\
(59.8- \\
155.6)\end{array}$ & 0.105 \\
\hline $\begin{array}{l}\text { Albumin- } \\
\text { corrected } \\
\text { calcium } \\
\text { (mg/dl) }\end{array}$ & $\begin{array}{l}8.8 \\
(8.5- \\
9.2)\end{array}$ & $\begin{array}{l}8.8 \\
(8.6- \\
9.1)\end{array}$ & 0.97 & $\begin{array}{l}\text { Visceral fat area } \\
\left(\mathrm{cm}^{2}\right)\end{array}$ & $\begin{array}{l}79.1 \\
(47.7- \\
119.3)\end{array}$ & $\begin{array}{l}69.4 \\
(33.1- \\
112.1)\end{array}$ & 0.097 \\
\hline \multicolumn{8}{|c|}{$\begin{array}{l}\text { [ Intergroup comparisons of parameters without correspondence were performed using the } \\
\text { Mann-Whitney U test and those with correspondence were performed using the Wilcoxon } \\
\text { signed-rank test. In addition, categorical variables have been presented as the number of } \\
\text { patients and compared using the chi-square test. } \mathrm{s} \text { s(P)RR, soluble (pro)renin receptor; DM, } \\
\text { diabetes mellitus; SBP, systolic blood pressure; RAS-I, renin-angiotensin system inhibitor; CCB, } \\
\text { calcium channel blocker; CTR, cardiothoracic ratio; Kt/V, normalized dialysis dose; HDL } \\
\text { cholesterol, high-density lipoprotein cholesterol; LDL cholesterol, low-density lipoprotein } \\
\text { cholesterol; CRP, C-reactive protein; hANP, human atrial natriuretic peptide; BNP, brain } \\
\text { natriuretic peptide; PRA, plasma renin activity; PAC, plasma aldosterone concentration; ARR, } \\
\text { aldosterone to renin ratio; LVEF, left ventricular ejection fraction; LVMI, left ventricular mass } \\
\text { index; E/e', E over e-prime; Dec-T, deceleration time; IMT, intima-media thickness; ABI, ankle- } \\
\text { brachial index; baPWV, brachial-ankle pulse wave velocity; CT, computed tomography }\end{array}$} \\
\hline
\end{tabular}


Table 2. Average of serum $s(P) R R$ levels in patients with each new-onset cardiovascular event

Cardiovascular death

$$
\mathrm{n}
$$

s(P)RR levels $(\mathrm{ng} / \mathrm{ml})$

Nonfatal myocardial infarction

$27 \quad 31.5(29.6-34.9)$

Unstable angina

$5 \quad 29.6(26.5-31.1)$

Heart failure 26 $29.1(25.6-32.4)$

Cerebral infarction or cerebral hemorrhage

12

$31.7(29.2-33.6)$

Severe lower limb ischemia (severe arteriosclerosis obliterans)

24

$30.6 \pm 7.2$

$\mathrm{s}(\mathrm{P}) \mathrm{RR}$, soluble (pro)renin receptor

Table 3. Average of serum $s(P) R R$ levels in patients with each new-onset malignant disease

$$
\mathrm{n} \quad \mathrm{s}(\mathrm{P}) \mathrm{RR} \text { levels }(\mathrm{ng} / \mathrm{ml})
$$

Gastrointestinal cancer

Stomach cancer

Colorectal cancer

Esophageal cancer

Appendiceal cancer

Liver, gallbladder, and pancreatic cancer

Hepatoma

Respiratory cancer

Lung cancer

Malignant pleural mesothelioma

Urinary organ cancer

Renal cancer

Bladder cancer

Prostate cancer

Others

Hypopharyngeal cancer

Breast cancer

Malignant melanoma

s(P)RR, soluble (pro)renin receptor
7

5

1

2

2

30.1

$32.2(29.0-37.6)$

29.6 (24.8-34.9)

31.7

35.8

6

1

$27.3(21.2-30.3)$

34.4

5

33.0 (26.1-33.8)

3

27.4 (26.4-29.7)

3

28.1 (24.7-32.3) 
Table 4. Univariate Cox regression analyses of variables for cardiovascular deaths

Variable

HR $\quad 95 \% \mathrm{CI}$

$\stackrel{P}{\mathrm{P}}$

HR $95 \% \quad P$

Background factors

Age

$\begin{array}{lll}1.055 & 1.027- & < \\ & 1.083 & 0.001\end{array}$

Inorganic

N.S. N.S. N.S.

Intact

parathyroid

$1.002 \quad 0.999-0.178$

hormone

Sex (male)

N.S. N.S. N.S.

Creatinine

$0.884 \quad 0.805-$

0.01

Body mass index

N.S. N.S. N.S.

Uric acid

N.S. N.S. N.S.

Primary disease

$1.778 \quad 1.076-0.025$

CRP

$1.184 \quad 0.916-0.197$

(DM) 2.935

N.S. N.S. N.S. Albumin

1.530

Duration of hemodialysis therapy (yes)

Smoking history

Urine volume

(more than $0 \mathrm{ml} /$ day)

SBP during dialysis

hANP

N.S. N.S. N.S.

BNP

N.S. N.S. N.S.

PRA

$0.324 \quad 0.142-0.008$

0.741

At the beginning

$0.988 \quad 0.974-$

1.001

Highest values

$0.986 \quad 0.973-$

0.999

Lowest values

$0.942 \quad 0.960-$

0.985

Difference (the

highest-the lowest)

At the end

$1.0121 .001-$

1.023

0.976

$0.964-$

0.07 PAC

0.032 ARR (PAC/PRA)

HbA1c

$1.0031 .002-<$

$1.004 \quad 0.001$

Medications (yes)

0.988

$<$

0.001

$1.0011 .001-$

$1.002 \quad 0.001$

N.S. N.S. N.S.

RAS-I

$\begin{array}{ll}0.478 & 0.283- \\ & 0.808\end{array}$

0.028

Physical function

tests

N.S. N.S. N.S.

$\beta$-blocker

N.S. N.S. N.S. E/e'

chocardiography

LVEF

$0.976 \quad 0.951-0.064$

1.001

CCB

$0.504 \quad 0.302-$

0.009

Dec-T

N.S. N.S. N.S.

$1.339 \quad 1.044-0.022$ 1.716

\begin{tabular}{lcccc} 
Statin & \multicolumn{3}{c}{0.842} & \\
& 2.35 & $1.332-$ & 0.003 & $\begin{array}{c}\text { Carotid ultrasound } \\
\text { examination }\end{array}$ \\
Phosphate binder & N.S. & N.146 & N.S. N.S. & Max carotid IMT
\end{tabular}

CTR

$\begin{array}{cccc}1.103 & 1.052- & < & \text { ABI } \\ & 1.155 & 0.001 & \\ \text { N.S. } & \text { N.S. } & \text { N.S. } & \text { Aver }\end{array}$

$\mathrm{Kt} / \mathrm{V}$

Blood tests

Lower values

N.S. N.S.

N.S.

N.S. N.S. N.S.

N.S. N.S. N.S.

S(P)RR

$\mathrm{s}(\mathrm{P}) \mathrm{RR}$

$1.057 \quad 1.020-$
1.095

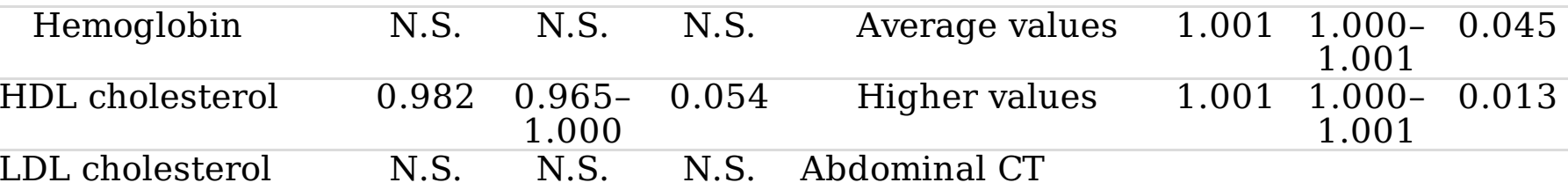

$\begin{array}{cccccccc}\text { Hemoglobin } & \text { N.S. } & \text { N.S. } & \text { N.S. } & \text { Average values } & 1.001 & 1.000- & 0.045 \\ & & & & & & 1.001 & \\ \text { HDL cholesterol } & 0.982 & 0.965- & 0.054 & \text { Higher values } & 1.001 & 1.000- & 0.013 \\ \text { LDL cholesterol } & \text { N.S. } & \text { N.S. } & \text { N.S. A Abdominal CT } & & & \end{array}$

0.003

baPWV

Average values

0.249

$0.072-0.028$

0.861

$\begin{array}{rr}1.952 & 1.219- \\ 3.127\end{array}$

0.005

Triglycerides

$\begin{array}{ccc}1.004 & 1.001- & 0.024 \\ & 1.007 & \end{array}$

Subcutaneous fat area

N.S. N.S. N.S. 
N.S.

HR, hazard ratio; CI, confidence intervals; N.S., not selected as a potential covariate; s(P)RR, soluble (pro)renin receptor; DM, diabetes mellitus; SBP, systolic blood pressure; RAS-I, renin-angiotensin system inhibitor; CCB, calcium channel blocker; CTR, cardiothoracic ratio; Kt/V, normalized dialysis dose; HDL cholesterol, high-density lipoprotein cholesterol; LDL cholesterol, low-density lipoprotein cholesterol; CRP, Creactive protein; hANP, human atrial natriuretic peptide; BNP, brain natriuretic peptide; PRA, plasma renin activity; PAC, plasma aldosterone concentration; ARR, aldosterone to renin ratio; LVEF, left ventricular ejection fraction; LVMI, left ventricular mass index; E/e', E over e-prime; Dec-T, deceleration time; IMT, intima-media thickness; ABI, ankle-brachial index; baPWV, brachial-ankle pulse wave velocity; CT, computed tomography 
Table 5. Multivariate Cox regression analyses of variables for cardiovascular deaths

Model 1

Including ABI, baPWV

Variable

S(P)RR

Age

Primary disease (DM)

Highest SBP values

Lowest SBP values

The difference in SBP values (the

highest-the lowest)

SBP values at the end

Medications (RAS-I)

Medications (CCB)

Medications (statin)

CTR

Triglycerides

Creatinine

Albumin

hANP

BNP

HbA1c

ABI (average values)

ABI (lower values)

BaPWV (average values)

BaPWV (higher values)

Max carotid IMT

\section{HR}

N.S.

1.039

N.S.

N.S.

0.970

N.S.

N.S.

N.S.

N.S.

2.555

1.083

N.S.

N.S.

N.S.

N.S.

$\begin{array}{lll}1.001 & 1.001- & < \\ & 1.002 & 0.001\end{array}$

N.S.

N.S.

N.S.

N.S.

N.S.

N.S.

N.S.

N.S.

N.S.

1.001

1.000

1.001

$0.354 \quad 0.121-$

1.038

N.S.

N.S.

N.S.

N.S.

N.S.

N.S.

N.S.

N.S.
Model 2

Excluding ABI, baPWV

value

HR $95 \% \mathrm{Cl}$

0.027

$1.041 \quad 1.001-$
1.083

$1.048 \quad 1.017-$

1.079

$1.900 \quad 1.101-$

3.278

N.S. N.S. N.S.

$\begin{array}{lll}0.981 & 0.969-0.002\end{array}$

0.001

N.S. N.S.

N.S.

value

0.046

0.002

0.021

N.S. N.S. N.S.

N.S. N.S. N.S.

N.S. N.S. N.S.

$2.975 \quad 1.544-$

5.730

$1.057 \quad 1.005-$

1.113

$1.003 \quad 0.999-$

1.008

0.001

0.033

0.159

$1.106 \quad 0.974-$

0.120

1.256

N.S. N.S.

N.S.

N.S. N.S. N.S.

$\begin{array}{lll}1.001 & 1.001- & <\end{array}$

N.S. N.S. N.S.

0.009

0.059

N.S.

\section{[}

口

$$
\text { प }
$$$$
\text { प }
$$

N.S. N.S.

ABI, ankle-brachial index; baPWV, brachial-ankle pulse wave velocity; HR, hazard ratio; CI, confidence interval; s(P)RR, soluble (pro)renin receptor; N.S., not selected as a potential covariate; DM, diabetes mellitus; SBP, systolic blood pressure; RAS-I, renin-angiotensin system inhibitor; CCB, calcium channel blocker; CTR, cardiothoracic ratio; CRP, C-reactive protein; hANP, human atrial natriuretic peptide; BNP, brain natriuretic peptide; IMT, intima-media thickness

\section{Figures}




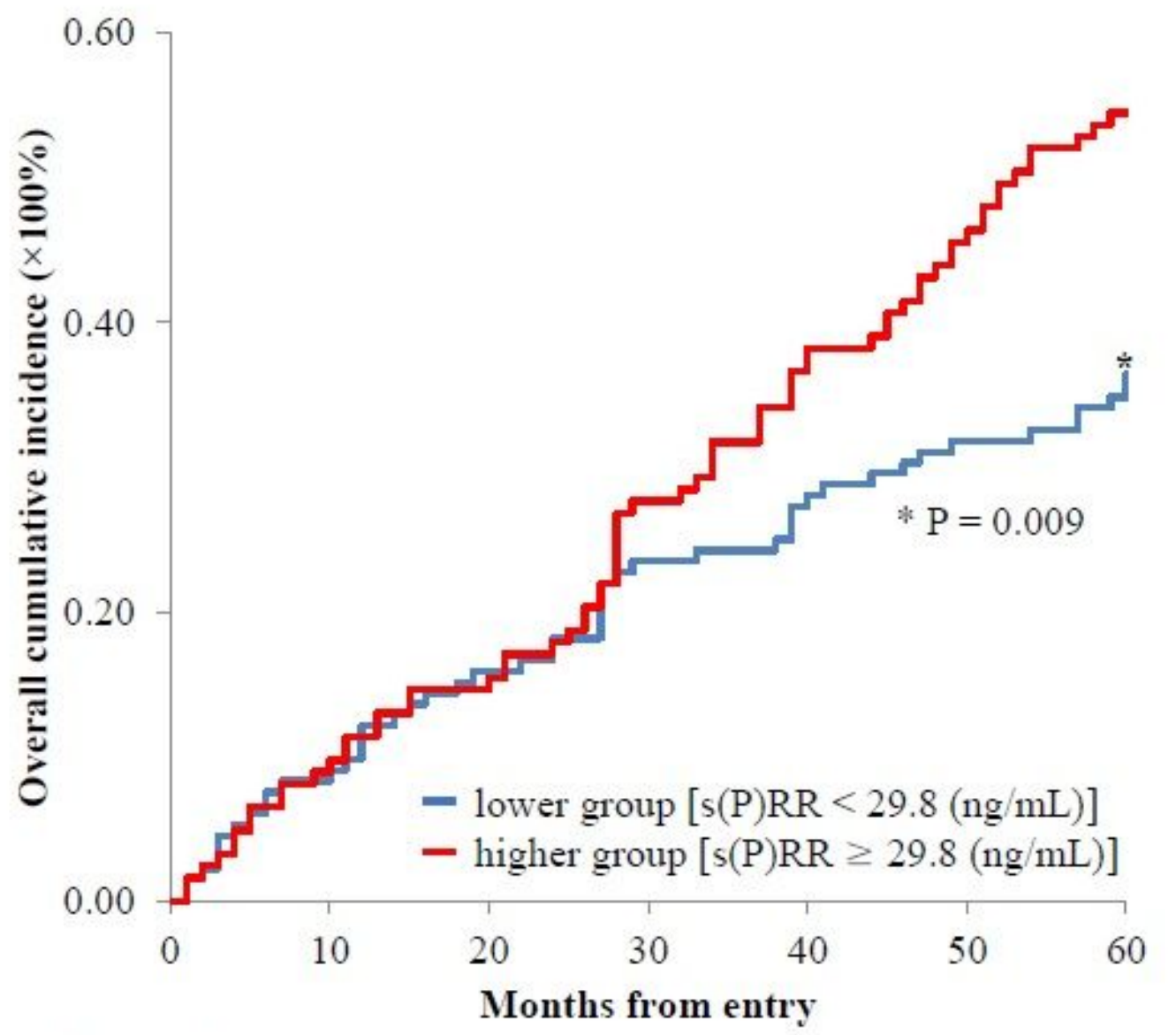

No. at risk

$\begin{array}{lllcccc}132 & 121 & 112 & 102 & 96 & 91 & 86 \\ 123 & 112 & 105 & 90 & 78 & 67 & 56\end{array}$

\section{Figure 1}

Cumulative probability of cardiovascular events. Kaplan-Meier plots comparing patients with higher and lower serum concentrations of $s(P) R R . s(P) R R$, soluble (pro)renin receptor 

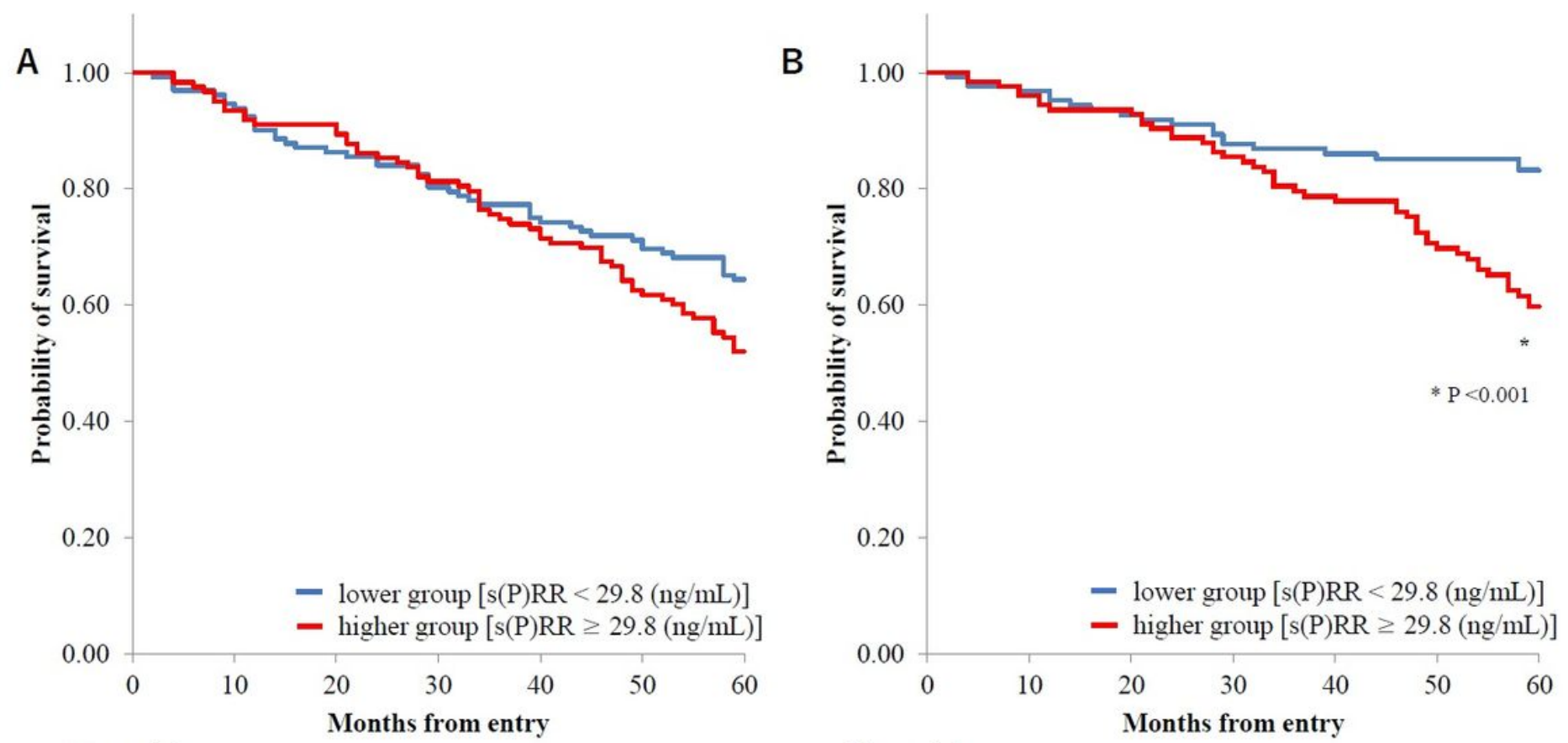

No. at risk

$\begin{array}{llllcll}133 & 125 & 115 & 109 & 102 & 94 & 85 \\ 125 & 117 & 112 & 101 & 90 & 77 & 64\end{array}$

No. at risk

$\begin{array}{lllllll}133 & 125 & 115 & 106 & 99 & 94 & 85 \\ 125 & 116 & 111 & 100 & 88 & 76 & 64\end{array}$

\section{Figure 2}

Probability of survival (A, All-cause death; B, Cardiovascular death) Kaplan-Meier survival plots comparing patients with higher and lower serum concentrations of $s(P) R R$. $s(P) R R$, soluble (pro)renin receptor 


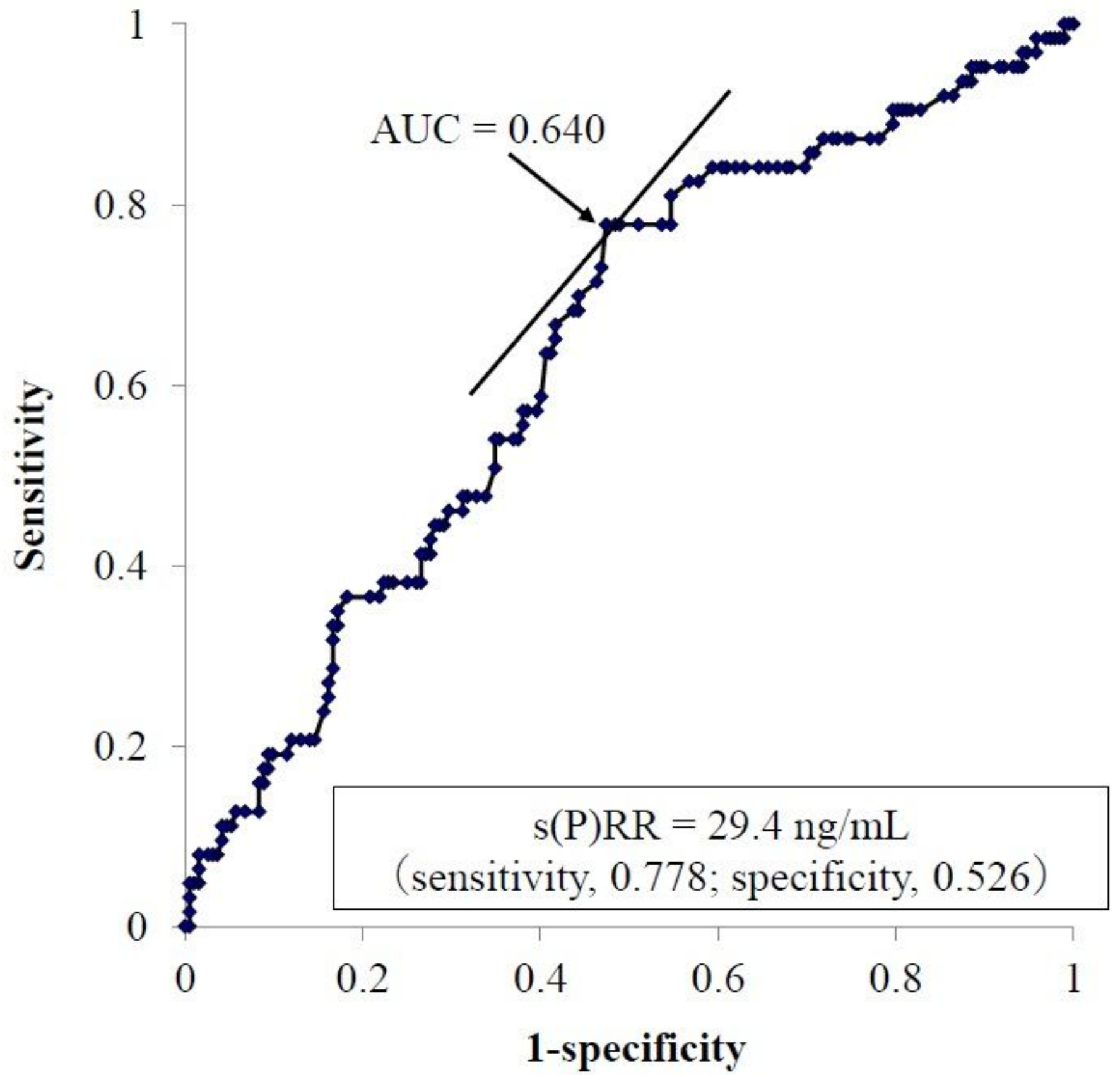

Figure 3

Receiver operating characteristic curve with area under the curve values Discrimination value of $s(P) R R$ for the survival rate using receiver operating characteristic analysis. AUC, area under the curve; $s(P) R R$, soluble (pro)renin receptor 